\title{
A Naphthalimide-Sulfonylhydrazine Conjugate as a Fluorescent Chemodosimeter for Hypochlorite
}

\author{
Yasuhiro Shiraishi *(D, Rikako Nakatani, Shunsuke Takagi, Chiharu Yamada and Takayuki Hirai \\ Research Center for Solar Energy Chemistry, and Division of Chemical Engineering, Graduate School of \\ Engineering Science, Osaka University, Toyonaka 560-8531, Japan; rikaco053cgda@gmail.com (R.N.); \\ s.takagi@cheng.es.osaka-u.ac.jp (S.T.); chiharu-y@tech-maseka.co.jp (C.Y.); hirai@cheng.es.osaka-u.ac.jp (T.H.) \\ * Correspondence: shiraish@cheng.es.osaka-u.ac.jp; Tel.: +81-6-6850-6271
}

Received: 15 October 2020; Accepted: 28 November 2020; Published: 1 December 2020

\begin{abstract}
Hypochlorite anion $\left(\mathrm{ClO}^{-}\right)$is a widely-used disinfectant and a microbicidal agent in the immune system. Accurate detection of $\mathrm{ClO}^{-}$in environmental and biological samples by simply prepared chemosensors/chemodosimeters is important. Herein, we report that a naphthalimide-sulfonylhydrazine conjugate with an imine $(\mathrm{C}=\mathrm{N})$ linker, prepared via simple condensation, acts as an effective fluorescent chemodosimeter for $\mathrm{ClO}^{-}$. The molecule exhibits a weak emission, but $\mathrm{ClO}^{-}$-selective cleavage of its $\mathrm{C}=\mathrm{N}$ bond creates a strong green emission. $\mathrm{Ab}$ initio calculation showed that the emission enhancement by $\mathrm{ClO}^{-}$originates from the suppression of intramolecular electron transfer from the photoexcited naphthalimide through the $\mathrm{C}=\mathrm{N}$ linker. This response enables selective and sensitive detection of $\mathrm{ClO}^{-}$at physiological $\mathrm{pH}$ range (7-9) and allows fluorometric $\mathrm{ClO}^{-}$imaging in the presence of cells.
\end{abstract}

Keywords: chemodosimeter; hypochlorite; fluorescence; naphthalimide; sulfonylhydrazine

\section{Introduction}

Hypochlorous acid $(\mathrm{HClO})$ is one important reactive oxygen species (ROS). $\mathrm{HClO}$ is formed in vivo by the enzymatic reaction of hydrogen peroxide $\left(\mathrm{H}_{2} \mathrm{O}_{2}\right)$ with chloride anion $\left(\mathrm{Cl}^{-}\right)$in some specialized cells such as neutrophils [1]. Deprotonation of $\mathrm{HClO}$ at a physiological $\mathrm{pH}$ range produces hypochlorite anion $\left(\mathrm{ClO}^{-}\right)$[2], which acts as an microbicidal agent in immune system [3]. The formed $\mathrm{ClO}^{-}$inhibits the invading microbes, but uncontrolled amounts of $\mathrm{ClO}^{-}$may result in several diseases such as arthritis [4], atherosclerosis [5], cancer [6], and Parkinson's disease [7] because $\mathrm{ClO}^{-}$reacts with several biomolecules [8]. Considerable amounts of $\mathrm{HClO}$ are used industrially or at home for sterilization, although high residual amounts of $\mathrm{ClO}^{-}$is hazardous [9]. A simple but inexpensive method to quantitatively detect small amount of $\mathrm{ClO}^{-}$is necessary.

One promising method for this purpose is fluorometric analysis using $\mathrm{ClO}^{-}$-selective molecular chemosensors/chemodosimeters because they facilitate simple quantification or imaging of $\mathrm{ClO}^{-}$with a common fluorescence spectrometer or microscope apparatus [10]. So far, various molecules based on several types of fluorescent dyes such as rhodamine, fluorescein, coumarin, diaminonaphthalene, and BODIPY have been proposed [11,12]. Several excellent molecules have successfully been applied to fluorescence imaging of $\mathrm{ClO}^{-}$in biological samples and quantification of very small amounts of $\mathrm{ClO}^{-}$in environmental samples. Challenges in the design and development of a new fluorescent chemosensors/chemodosimeters with higher reactivity toward $\mathrm{ClO}^{-}$are still ongoing. Among the fluorescent dyes, naphthalimide is one of the popular dyes often used in the synthesis of chemosensors/chemodosimeters because of its high chemical stability, high photostability, a large Stokes shift, and a strong fluorescence quantum yield [13]. There is, however, a few naphthalimide-based 
molecules for fluorometric detection of $\mathrm{ClO}^{-}$[14-16]. Therefore, creating a new naphthalimide-based chemosensor/chemodosimeter is an important issue.

Recently, an imine $(\mathrm{C}=\mathrm{N})$ moiety has been used as a linker to connect a fluorescent dye unit with an electron accepting unit in the design of chemosensors/chemodosimeters for $\mathrm{ClO}^{-}$detection [17-19]. This is because the $\mathrm{C}=\mathrm{N}$ linker (i) facilitates an intramolecular electron transfer between the two units; (ii) behaves as a reaction site for $\mathrm{ClO}^{-}$and affects the electron transfer efficiency; and, (iii) can be created by a facile condensation of two reactive groups such as aldehydes and amines. The simple system using a $\mathrm{C}=\mathrm{N}$ linker may become a versatile design of chemodosimeters for fluorometric detection of $\mathrm{ClO}^{-}$.

In the present work, we synthesized a simple naphthalimide-sulfonylhydrazine conjugate (1) through the $\mathrm{C}=\mathrm{N}$ linker (Scheme 1) and studied the effects of the sulfonylhydrazine moiety on the reactivity of the $\mathrm{C}=\mathrm{N}$ reaction site towards $\mathrm{ClO}^{-}$and the change in the emission/optical properties. This molecule, when dissolved in an aqueous solution, shows a weak fluorescence. Addition of $\mathrm{ClO}^{-}$ to the solution selectively enhances fluorescence emission via an oxidative cleavage of the $\mathrm{C}=\mathrm{N}$ moiety. This off-on fluorometric response facilitate rapid, selective, and sensitive detection of $\mathrm{ClO}^{-}$in neutral media with $\mathrm{pH} 7-9$ and also allows $\mathrm{ClO}^{-}$imaging in the presence of cells.

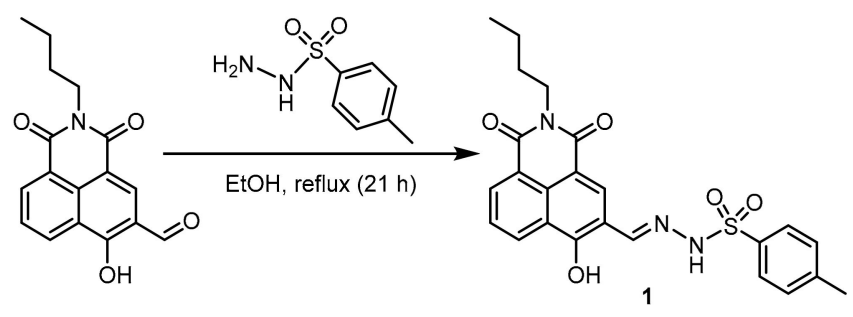

Scheme 1. Synthesis of the chemodosimeter 1.

\section{Materials and Methods}

\subsection{General}

All chemicals were used without further purification. Hydroxyl radical $(\cdot \mathrm{OH})$, peroxynitrile $\left(\mathrm{ONOO}^{-}\right)$, and superoxide radical $\left(\cdot \mathrm{O}_{2}^{-}\right)$were generated according to the procedure described $[20,21]$. Fluorescence spectra were measured on a JASCO FP-6500 fluorescence spectrophotometer (JASCO Corp., Tokyo, Japan) at $298 \pm 1 \mathrm{~K}$ [22]. Absorption spectra were measured on an UV-visible spectrometer (Shimadzu Corp., Kyoto, Japan; UV-3600 plus) at $298 \pm 1 \mathrm{~K}$ [23]. ${ }^{1} \mathrm{H}$ and ${ }^{13} \mathrm{C}$ NMR spectra were obtained on a JEOL JNM-ECS400 Spectrometer (JEOL Ltd., Tokyo, Japan). FAB-MS analysis was performed on a JEOL JMS 700 Mass (JEOL Ltd., Tokyo, Japan). $\Phi_{\mathrm{F}}$ was determined with rhodamine $B$ (in ethanol) as a standard [24], using the refractive indexes for water and ethanol being 1.3334 and 1.3618 , respectively [25]. Ab initio calculations were performed within the Gaussian 03 package using the B3LYP/6-3G+(d) basis set for all atoms. Cartesian coordinates of the models are summarized at the end of Supplementary Material.

\subsection{Synthesis}

4-Hydroxy- $N$-butyl-1,8-naphthalimide was synthesized according to literature procedure [26]. 3-Formyl-4-hydroxy- $N$-butyl-1,8-naphthalimide was synthesized according to literature procedure [27] using 4-hydroxy- $N$-butyl-1,8-naphthalimide. Its purity was confirmed by the ${ }^{1} \mathrm{H},{ }^{13} \mathrm{C}$ NMR, and $\mathrm{FAB}(+)$-MS charts (Figures S1-S3, Supplementary Material).

The compound 1 was synthesized as follows: 3-formyl-4-hydroxy- $N$-butyl-1,8-naphthalimide ( $296 \mathrm{mg}, 1.0 \mathrm{mmol}$ ) and commercially available $p$-toluenesulfonyl hydrazide $(273 \mathrm{mg}, 1.5 \mathrm{mmol}$ ) were dissolved in ethanol $(20 \mathrm{~mL})$ and refluxed at $80^{\circ} \mathrm{C}$ for $21 \mathrm{~h}$. The formed precipitate was recovered by suction filtration with washing using ethanol, affording 1 as a yellow solid. Yield: $402.5 \mathrm{mg}$ 
(0.865 mmol) (87\%). ${ }^{1} \mathrm{H}$ NMR (400 MHz, DMSO-d $\left.6, \mathrm{TMS}\right), \delta(\mathrm{ppm}): 0.87(\mathrm{t}, 3 \mathrm{H}, J=10.8 \mathrm{~Hz}), 1.24-1.33$ $(\mathrm{m}, 2 \mathrm{H}), 1.50-1.57(\mathrm{~m}, 2 \mathrm{H}), 2.32(\mathrm{~s}, 3 \mathrm{H}), 3.95(\mathrm{t}, 2 \mathrm{H}, J=14.8 \mathrm{~Hz}), 7.42(\mathrm{~d}, 2 \mathrm{H}, J=8.0 \mathrm{~Hz}), 7.75(\mathrm{t}, 1 \mathrm{H}$, $J=12.0 \mathrm{~Hz}), 7.78(\mathrm{~d}, 2 \mathrm{H}, J=5.2 \mathrm{~Hz}), 8.41(\mathrm{~d}, 1 \mathrm{H}, J=6.0 \mathrm{~Hz}), 8.42(\mathrm{~s}, 1 \mathrm{H}), 8.46(\mathrm{~s}, 1 \mathrm{H}), 8.54(\mathrm{~d}, 1 \mathrm{H}, J=8.8$ $\mathrm{Hz}), 12.21$ (s, 1H). ${ }^{13} \mathrm{C}$ NMR (400 MHz, DMSO-d $\left.6, \mathrm{TMS}\right), \delta$ (ppm): 14.22, 20.30, 21.54, 30.20, 114.24, $114.52,122.60,123.17,127.18,127.64,129.40,129.63,130.53,132.47,132.63,136.09,144.57,148.43,159.72$, 163.18, and 163.86. FAB-MS $(m / z)$ calcd for $\mathrm{C}_{24} \mathrm{H}_{23} \mathrm{~N}_{3} \mathrm{O}_{5} \mathrm{~S}[\mathrm{M}+\mathrm{H}]^{+}:$466.1358, found (FAB) 466.1443.

\subsection{Biological Experiments}

Cell culture and fluorescence microscopy observations were carried out as follows. HeLa cells were grown in the Dulbecco's modified Eagle's medium (DMEM) supplemented with 10\% fetal bovine serum on a cover slip in $100 \mathrm{~mm}$ dishes. All of the cells were incubated at $37^{\circ} \mathrm{C}$ in humidified air containing $5 \% \mathrm{CO}_{2}$. The cells were treated with a phosphate buffered saline (PBS)/MeCN (8/2 v/v) mixture containing $1(50 \mu \mathrm{M})$ followed by different concentrations of $\mathrm{ClO}^{-}$for $30 \mathrm{~min}$, respectively. The cells were washed with PBS and subjected for observation on a fluorescence microscopy (BIOREVE BZ-9000, Keyence Corp., Osaka, Japan) [28]. Cell viability tests were performed as follows [29]: Trypsinized HeLa cells were incubated with PBS/MeCN (8/2 v/v) mixture containing 1 (50 $\mu \mathrm{M})$ for $20 \mathrm{~min}$ at $37^{\circ} \mathrm{C}$ in humidified air containing $5 \% \mathrm{CO}_{2}$. After washing with PBS for three times, a Trypan blue solution was added to the cells. The respective live and dead cells were counted using the Countess II FL Automated Cell Counter.

\section{Results and Discussion}

\subsection{Chemodosimeter Synthesis}

The chemodosimeter $\mathbf{1}$ was successfully synthesized via a condensation of 3-formyl-4-hydroxy-N-butyl-1,8-naphthalimide [27] with $p$-toluenesulfonyl hydrazide (Scheme 1). An ethanol solution containing these reagents was refluxed at $80{ }^{\circ} \mathrm{C}$ for $21 \mathrm{~h}$. Suction filtration of the resultant with simple washing using EtOH afforded yellow powders of 1 with high yield (87\%). The purity of 1 was confirmed by ${ }^{1} \mathrm{H}$ NMR, ${ }^{13} \mathrm{C}$ NMR, ${ }^{1} \mathrm{H}-{ }^{1} \mathrm{H}$ COSY, and FAB(+)-MS analysis (Figures S4-S7, Supplementary Material). The high yield of 1 by simple reflux and washing with EtOH is a noticeable advantage of this chemodosimeter.

\subsection{Fluorescence Properties}

Fluorescence spectra were obtained in a buffered water/MeCN mixture $(8 / 2 v / v)$ with pH 7.0 (HEPES $0.1 \mathrm{M})$ at $25{ }^{\circ} \mathrm{C}\left(\lambda_{\mathrm{ex}}=365 \mathrm{~nm}\right)$. As shown in Figure $1 \mathrm{a}, 1$ exhibits only a weak emission (fluorescence quantum yield, $\Phi_{\mathrm{F}}=0.01$ ). Addition of 50 equiv of $\mathrm{ClO}^{-}$to the solution creates a strong green fluorescence centred at $519 \mathrm{~nm}\left(\Phi_{\mathrm{F}}=0.15\right)$. However, addition of other anions $\left(\mathrm{F}^{-}, \mathrm{Cl}^{-}\right.$, $\left.\mathrm{Br}^{-}, \mathrm{AcO}^{-}, \mathrm{NO}_{2}{ }^{-}, \mathrm{NO}_{3}{ }^{-}\right)$, other $\mathrm{ROS}\left[\cdot \mathrm{OH}, \mathrm{H}_{2} \mathrm{O}_{2}, \cdot \mathrm{O}_{2}{ }^{-}\right.$, and tert-butyl hydroperoxide $\left.(t-\mathrm{BuOOH})\right]$, or reactive nitrogen species (RNS) $\left[\mathrm{ONOO}^{-}\right]$barely change the spectrum of 1 , indicating that $\mathrm{ClO}^{-}$ selectively triggers fluorescence enhancement of $\mathbf{1}$. It must be noted that, as shown in Figure $1 \mathrm{~b}$, the $519 \mathrm{~nm}$ fluorescence enhanced by $\mathrm{ClO}^{-}$is unaffected by the other contaminants, suggesting that 1 selectively detects $\mathrm{ClO}^{-}$even in the presence of these contaminants.

As shown in Figure 2a, the fluorescence titration of $\mathbf{1}$ with $\mathrm{ClO}^{-}$increases the intensity of the 519 $\mathrm{nm}$ fluorescence. A linear relationship between the fluorescence intensity and $\mathrm{ClO}^{-}$amount (Figure 2b) indicates accurate $\mathrm{ClO}^{-}$sensing at $\sim 100 \mu \mathrm{M}$. The lower detection limit (DL) was determined based on the signal-to-noise ratio using the equation $(\mathrm{DL}=3 \times \mathrm{SD} / S)$ [30], where $\mathrm{SD}$ is the standard deviation of blank measurement ( $\mathrm{SD}=0.061, n=11$ ) and $S$ is the slope of the fluorescence intensity versus the $\mathrm{ClO}^{-}$concentration $\left(S=0.096 \mu \mathrm{M}^{-1}\right)$. This DL determined $(1.9 \mu \mathrm{M})$ is below the physiological $\mathrm{ClO}^{-}$concentrations $(5-25 \mu \mathrm{M})$ in neutrophils [31], suggesting that 1 also facilitates sensitive $\mathrm{ClO}^{-}$ detection. The chemodosimeter $\mathbf{1}$, when left in a solution for 1 day, shows absorption and fluorescence spectra similar to those of the fresh molecule. In addition, the solution, when treated with $\mathrm{ClO}^{-}$, shows 
spectral responses similar to those of the fresh sample. This means that $\mathbf{1}$ is storable in solution and can stably be used for $\mathrm{ClO}^{-}$sensing.
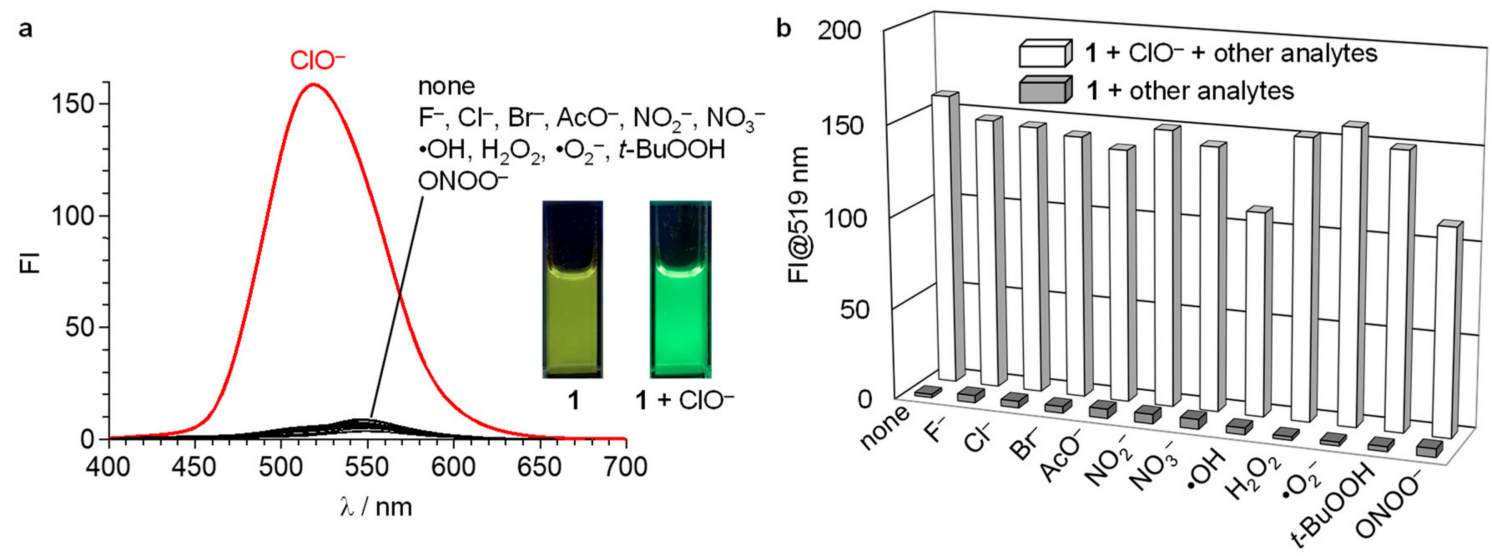

Figure 1. (a) Fluorescence spectra of $\mathbf{1}(10 \mu \mathrm{M})$ in a buffered water/MeCN mixture $(8 / 2 v / v, \mathrm{pH} 7.0)$ at $25^{\circ} \mathrm{C}$ with 50 equiv of each analyte. (b) Intensity obtained (grey) with 50 equiv of each analyte and (white) 50 equiv of $\mathrm{ClO}^{-}$and analytes. All spectra were measured after stirring the solution for $10 \mathrm{~min}$. The salts used are: $\mathrm{NaF}, \mathrm{KCl}, \mathrm{NaBr}, \mathrm{AcONa}, \mathrm{NaNO}_{2}$, and $\mathrm{KNO}_{3}$.
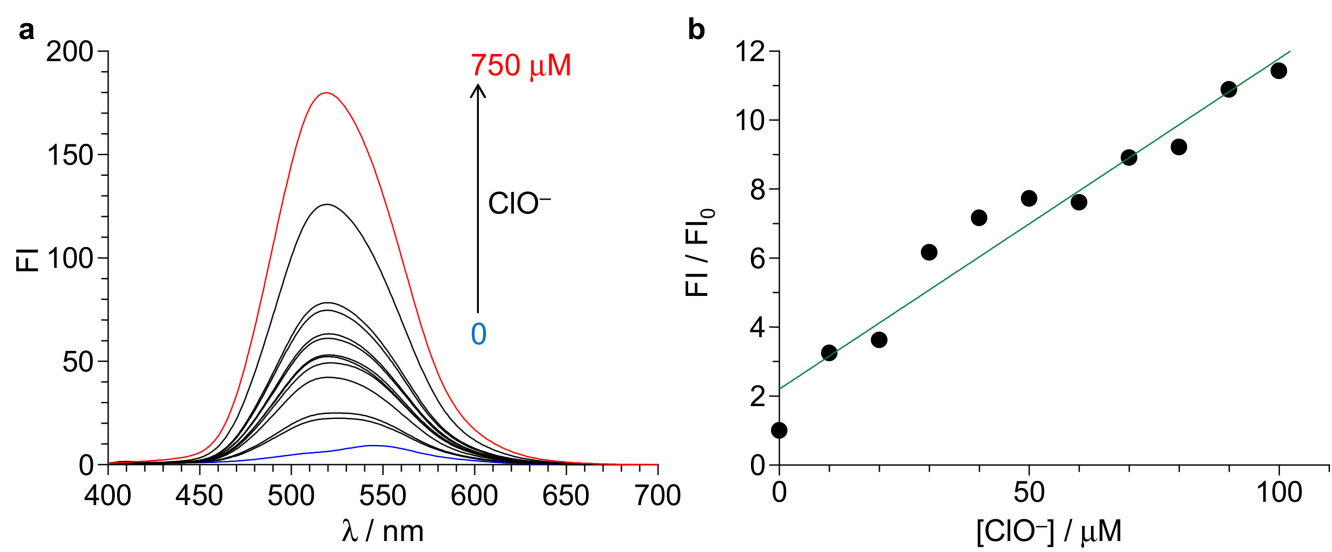

Figure 2. (a) Fluorescence spectra of $1(10 \mu \mathrm{M})$ upon titration with $\mathrm{ClO}^{-}$. (b) Plots of the intensity ratio at $519 \mathrm{~nm}$ versus the $\mathrm{ClO}^{-}$concentrations.

\subsection{Emitting Species}

To identify the green emitting species formed by the reaction of 1 with $\mathrm{ClO}^{-}$, we tried to isolate the species from the resulting solution. Concentration of the solution by evaporation followed by a thin-layer chromatography (TLC) analysis ( $n$-hexane/EtOAc $=1 / 1 v / v)$ of the resultant (Figure S8, Supplementary Material) shows a single emitting spot $\left(R_{f}=0.70\right)$, where the $R_{f}$ of $\mathbf{1}$ is 0.25 . This suggests that the reaction of 1 with $\mathrm{ClO}^{-}$produces a single emitting species. ${ }^{1} \mathrm{H}$ NMR analysis (DMSO- $\mathrm{d}_{6}$ ) of the fraction eluted using a silica gel column containing the green emitting species showed several impurity protons, where strong protons appear at $\sim 2.4 \mathrm{ppm}, \sim 7.2 \mathrm{ppm}$, and $\sim 7.6 \mathrm{ppm}$, respectively, with the integration ratio being $3: 2: 2$, which are assigned to the aromatic protons of the $p$-toluenesulfonic acid moiety. This indicates that the sulfonylhydrazine moiety of $\mathbf{1}$ is decomposed during the reaction with $\mathrm{ClO}^{-}$, and the formed fragments elute with the green emitting species owing to their similar high polarities. As a result of this, the isolation and ${ }^{1} \mathrm{H} N M R$ analysis of the emitting species were unsuccessful. 
The crude product was then analyzed by FAB-MS. As shown in Figure S7 (Supplementary Material), 1 exhibits a clear molecular ion at $m / z 466.2\left(\mathrm{FAB}(+)\right.$ mode), assigned to the $\left[1+\mathrm{H}^{+}\right]^{+}$ species. In contrast, as shown in Figure S9 (Supplementary Material), the crude product does not show a clear molecular ion, but a very strong ion appears at $\mathrm{m} / z 296.2(\mathrm{FAB}(+))$. $\mathrm{ClO}^{-}$oxidizes the $\mathrm{C}=\mathrm{N}$ moieties and produces $\mathrm{C}=\mathrm{N}$ cleaved aldehydes or carboxylic acids by hydrolysis [17-19]. Therefore, as proposed in Scheme 2 (right top), the $m / z 296.2$ ion (FAB $(+)$ ) may be assigned to the species containing an oxetane moiety $\left(\left[2-\mathrm{H}_{2} \mathrm{O}+\mathrm{H}^{+}\right]^{+}\right)$, which may be produced by intramolecular dehydration of the compound 2 during the FAB ionization. In addition, as shown in Figure S10 (Supplementary Material), the chart in the FAB(-) mode shows a strong molecular ion at $\mathrm{m} / \mathrm{z} 312.08$, which is assigned to the $\left[2-\mathrm{H}^{+}\right]^{-}$species formed by deprotonation of $\mathbf{2}$ during the FAB ionization (Scheme 2, right bottom). This clearly suggests that the $\mathrm{C}=\mathrm{N}$ cleaved carboxylic acid (2) is the green emitting species. It is reported that some $\mathrm{C}=\mathrm{N}$-based chemodosimeters produce aldehyde as the product by the reaction with $\mathrm{ClO}^{-}[17,19]$. However, as shown in Figure S3 (Supplementary Material), 3-formyl-4-hydroxy- $N$-butyl-1,8-naphthalimide (3) [27], the starting material for the synthesis of 1 (Scheme 1, left), shows a molecular ion at $m / z 298.2\left(\left[3+\mathrm{H}^{+}\right]^{+}\right)$in the $\mathrm{FAB}(+)$ mode. MS analysis of a solution containing 3 , when treated with $\mathrm{ClO}^{-}$under the conditions similar to the present sensing, shows a $\mathrm{FAB}(+)$ chart similar to that of 3 , suggesting that 3 is not oxidized to the carboxylic acid (2) by the reaction with $\mathrm{ClO}^{-}$under the present condition. This indicates that, as shown in Scheme 2, the emitting species (2) is formed directly by the $\mathrm{C}=\mathrm{N}$ cleavage of $\mathbf{1}$, where the aldehyde (3) is not involved as an intermediate.

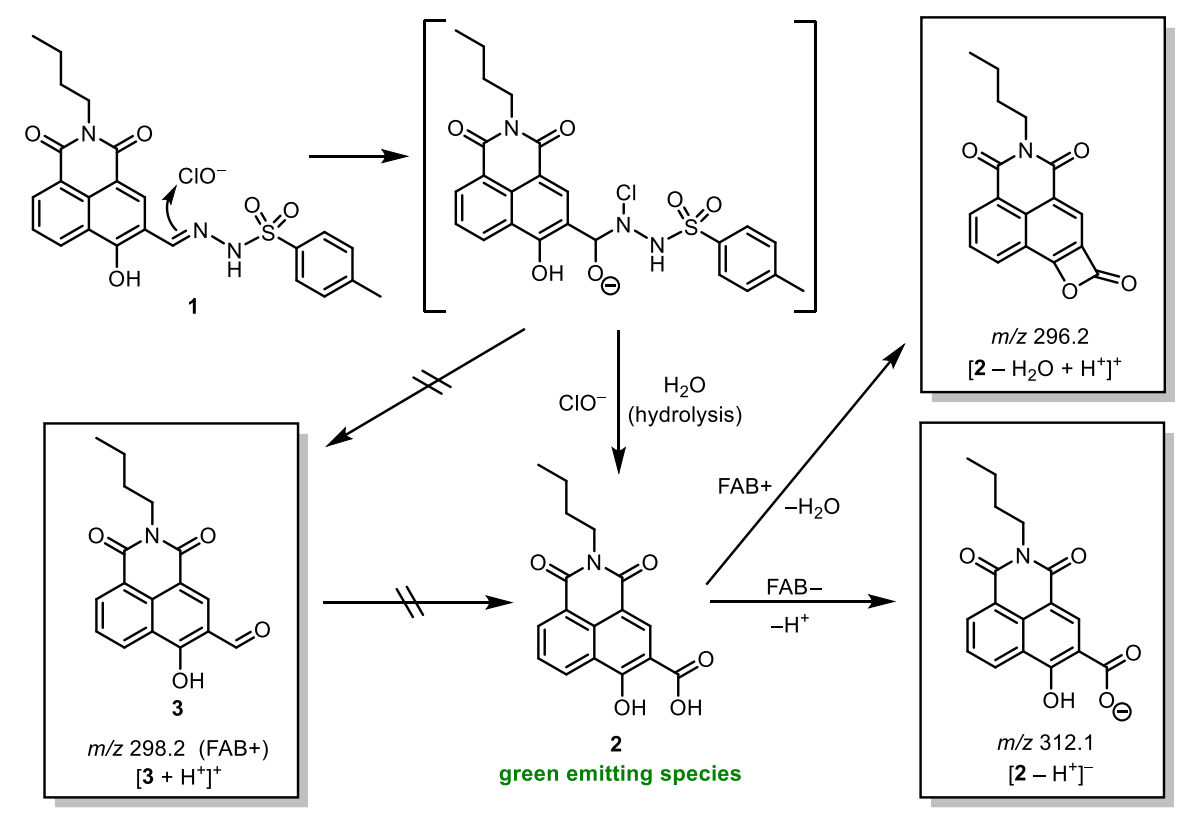

Scheme 2. Proposed mechanism for the reaction of $\mathbf{1}$ with $\mathrm{ClO}^{-}$.

\subsection{Reaction Mechanism}

The proposed sequence (Scheme 2) is confirmed by the fluorescence and absorption spectra of $\mathbf{1}$ upon reaction with $\mathrm{ClO}^{-}$. As shown in Figure 3a, addition of $\mathrm{ClO}^{-}$increases the $519 \mathrm{~nm}$ fluorescence. As shown in the inset, the intensity increases with time and becomes plateaus after $600 \mathrm{~s}$ (10 min). During the measurement, the emission wavelengths barely change, suggesting the formation of a single emitting species (2), which is supported by the single emitting spot observed in TLC analysis (Figure S8, Supplementary Material). As shown in Figure $3 \mathrm{~b}$, the $\mathrm{ClO}^{-}$addition immediately changes the absorption spectrum of 1 within $1 \mathrm{~min}$ (blue $\rightarrow$ red) with an isosbestic point at $311 \mathrm{~nm}$. The spectrum further changes with a decrease in the absorbance at $327 \mathrm{~nm}$ with an isosbestic point at $454 \mathrm{~nm}$, finally exhibiting a peak at $429 \mathrm{~nm}$. As shown by the inset, the time profile for the decrease in the $327 \mathrm{~nm}$ 
absorbance is consistent with the profile for the fluorescence intensity increase (inset of Figure 3a). These findings indicate that, as shown in Scheme 2, the reaction of 1 with $\mathrm{ClO}^{-}$produces some $\mathrm{C}=\mathrm{N}$ cleaved intermediates, and further oxidation by $\mathrm{ClO}^{-}$with hydrolysis produces the green emitting species (2).

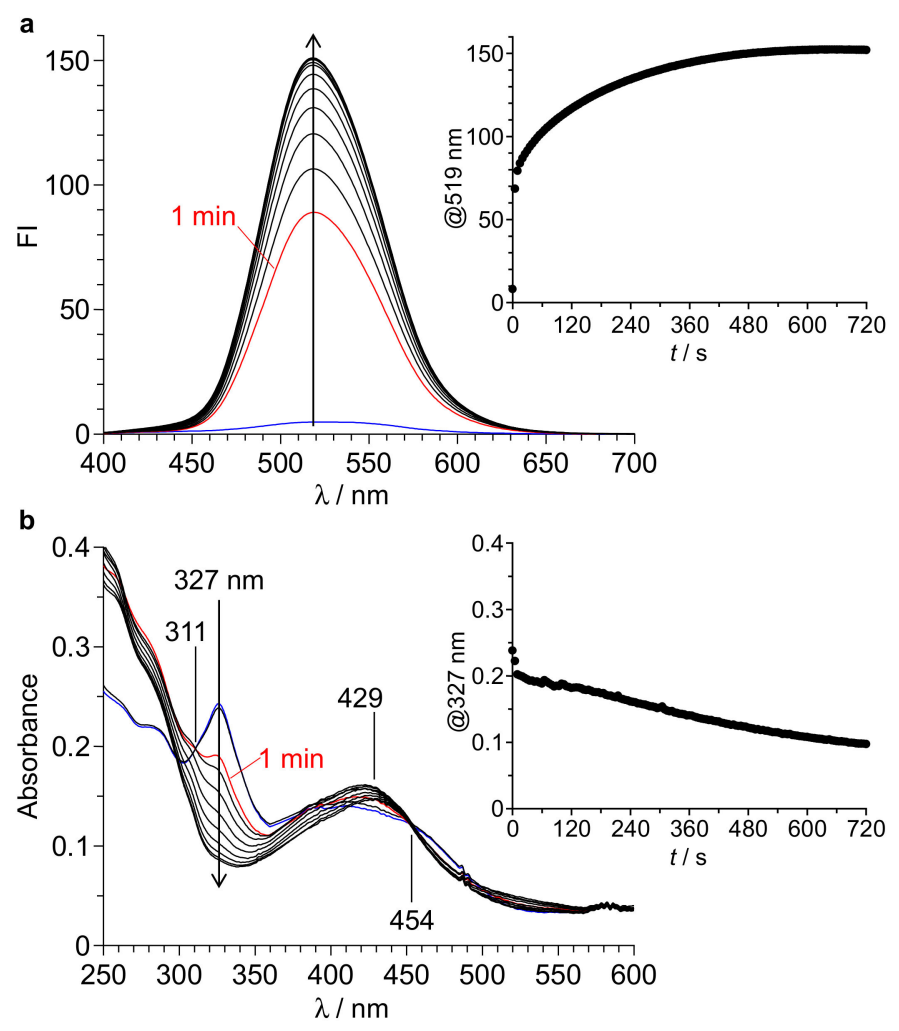

Figure 3. (a) Change in fluorescence spectra of $\mathbf{1}$ in a buffered water/MeCN mixture (8/2 v/v, pH 7.0) after addition of 50 equiv of $\mathrm{ClO}^{-}$. (b) Change in absorption spectra of $\mathbf{1}$ after addition of $\mathrm{ClO}^{-}$.

The hydrolysis is indeed involved in the reaction mechanism (Scheme 2). Figure 4 shows the change in fluorescence intensity of $\mathbf{1}$ after addition of $\mathrm{ClO}^{-}$in the $\mathrm{MeCN}$ solutions with different water amounts. Without water, 1 shows only a small fluorescence enhancement by $\mathrm{ClO}^{-}$. Increasing the water amount in the solution increases the enhancement by $\mathrm{ClO}^{-}$. This indicates that, as shown in Scheme 2, hydrolysis of the intermediates produces the carboxylic acid emitting species (2). It must also be noted that the fluorescence enhancement by $\mathrm{ClO}^{-}$is reduced in solution with $>90 \%$ water. This is probably because the decreased solubility of $\mathbf{1}$ suppresses the reaction with $\mathrm{ClO}^{-}$, suggesting that sufficient dissolution of $\mathbf{1}$ in solution is necessary for the fluorometric $\mathrm{ClO}^{-}$detection.

It must be noted that ${ }^{1} \mathrm{H}$ NMR analysis of the product indicates that the reaction of $\mathbf{1}$ with $\mathrm{ClO}^{-}$produces $p$-toluenesulfonic acid as a byproduct. This means that 1 , when used for biological experiments, leaves $p$-toluenesulfonic acid in the body or cell systems. It has been clarified that sulfonic acid compounds have a low systemic toxicity and are neither mutagenic nor carcinogenic regardless of the structure and the route or duration of the application [32]. In addition, some sulfonic acid-containing molecules have successfully been used for cell imaging [33,34]. These findings indicate that the $p$-toluenesulfonic acid byproduct may not have a negative effect on the biological applications. 


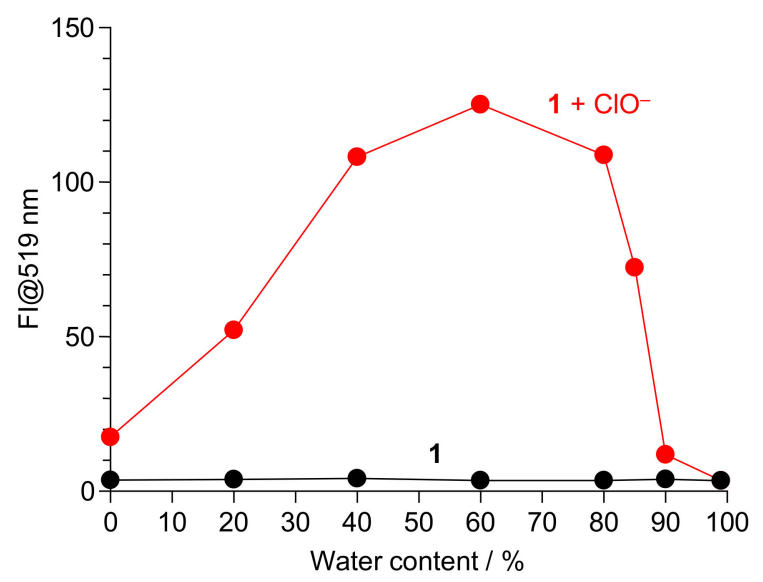

Figure 4. Effect of water content on the fluorescence intensity of $\mathbf{1}(10 \mu \mathrm{M})$ in the absence or presence of 50 equiv of $\mathrm{ClO}^{-}$in a buffered water/MeCN mixture (8/2 v/v; HEPES 0.1 M, pH 7.0) at $25{ }^{\circ} \mathrm{C}$. The respective data were obtained after stirring the solution for $10 \mathrm{~min}$.

\subsection{Ab Initio Calculations}

To further confirm $\mathbf{2}$ as the green emitting species, structures and optical properties of $\mathbf{1}$ and 2 were calculated by the density functional theory (DFT) and the time-dependent DFT (TD-DFT), respectively [35]. As shown in Table S1 (Supplementary Material), singlet electronic transition of 1 mainly consists of $\mathrm{HOMO} \rightarrow \mathrm{LUMO}+1\left(\mathrm{~S}_{0} \rightarrow \mathrm{S}_{4}\right)$ transition. Its calculated transition energy (4.03 $\mathrm{eV}, 308 \mathrm{~nm}$ ) is close to the absorption maximum $\left(\lambda_{\max }\right)$ of $\mathbf{1}$ at $327 \mathrm{~nm}$ (Figure $3 \mathrm{~b}$ ). As shown in Figure 5 (left), $\pi$-electrons of the main orbitals of 1 such as HOMO, LUMO, and LUMO+1 are located on the naphthalimide moiety and the $\mathrm{C}=\mathrm{N}$ moiety. This indicates that photoexcited electrons on the naphthalimide moiety are transferred to the $p$-toluenesulfonyl moiety via the $\mathrm{C}=\mathrm{N}$ linker. This may result in almost no fluorescence of $\mathbf{1}$.
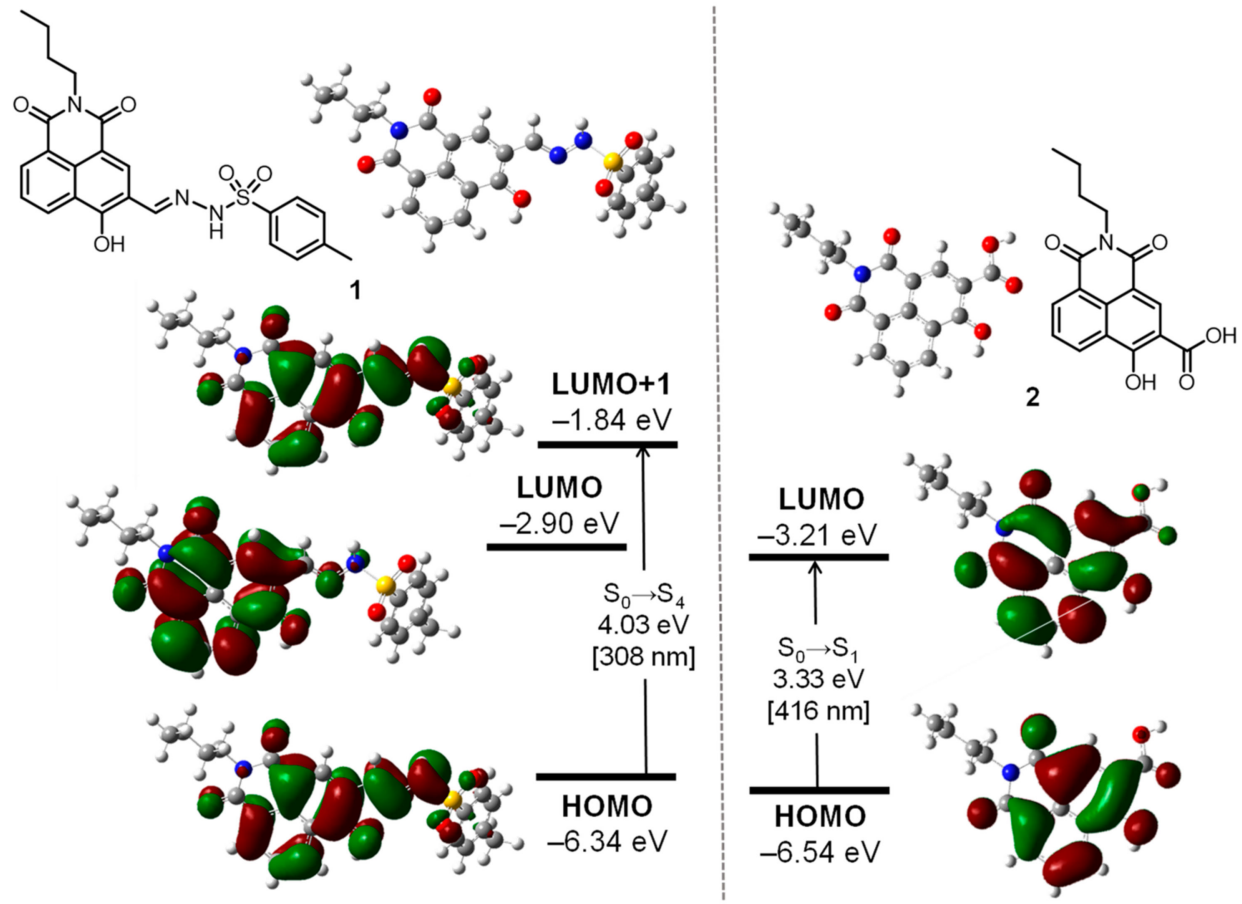

Figure 5. Calculated energy diagrams and interfaces of main molecular orbitals of (left) 1 and (right) 2 (TD-DFT/B3LYP/6-31G+(d)). 
As shown in Table S1 (Supplementary Material), the electronic excitation of 2 consists of HOMO $\rightarrow$ LUMO $\left(\mathrm{S}_{0} \rightarrow \mathrm{S}_{1}\right)$ transition. Its energy $(2.98 \mathrm{eV}, 416 \mathrm{~nm})$ is consistent with the absorption band of 1 at $429 \mathrm{~nm}$ after addition of $\mathrm{ClO}^{-}$(Figure $3 \mathrm{~b}$ ). As shown in Figure 5 (right), $\pi$-electrons of both $\mathrm{HOMO}$ and LUMO are located on the naphthalimide moiety, indicating that the $\mathrm{C}=\mathrm{N}$ cleavage of $\mathbf{1}$ suppresses electron transfer from the photoexcited naphthalimide moiety. This may facilitate strong fluorescence from the carboxylic acid (2). These data support the proposed reaction mechanism of 1 with $\mathrm{ClO}^{-}$ (Scheme 2).

\subsection{Effect of $p H$}

The chemodosimeter 1 facilitates $\mathrm{ClO}^{-}$sensing at neutral $\mathrm{pH}(7-9)$. Figure 6 shows the fluorescence intensity of $\mathbf{1}$ at different $\mathrm{pH}$, with and without $\mathrm{ClO}^{-}$. Also shown are the mole fractions of $\mathrm{HClO}$ and $\mathrm{ClO}^{-}$, calculated based on their equilibrium in water [36]:

$$
\mathrm{HClO} \rightleftharpoons \mathrm{ClO}^{-}+\mathrm{H}^{+}\left(\mathrm{p} K_{\mathrm{a}}=7.6\right)
$$

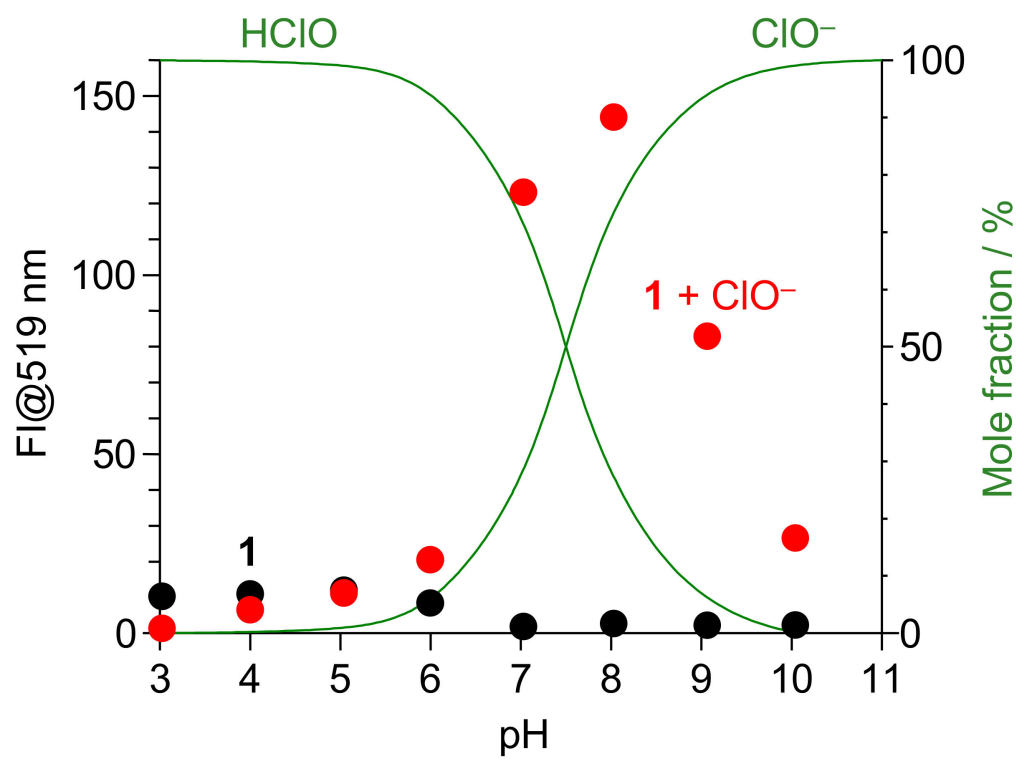

Figure 6. Fluorescence intensity of $\mathbf{1}$ at $519 \mathrm{~nm}$ in water/MeCN mixtures $(8 / 2 v / v)$ with different $\mathrm{pH}$, (red) with and (black) without $\mathrm{ClO}^{-}$(50 equiv). The mole fraction of $\mathrm{HClO}$ and $\mathrm{ClO}^{-}$calculated based on Equation 1 are also shown.

$\mathrm{ClO}^{-}$enhances the intensity of $\mathbf{1}$ at a neutral $\mathrm{pH}$ (7-9). At $\mathrm{pH}<7$, protonation of $\mathrm{ClO}^{-}(\mathrm{HClO}$ formation) cancels the basicity of $\mathrm{ClO}^{-}$and inhibits the reaction with the $\mathrm{C}=\mathrm{N}$ moiety of 1 . At $\mathrm{pH}>9$, $\mathrm{ClO}^{-}$is stabilized in solution, but the fluorescence enhancement decreases significantly. This is because, as reported for some $\mathrm{ClO}^{-}$chemodosimeters [37-39], the oxidation ability of $\mathrm{ClO}^{-}$decreases in basic media and inhibits the reaction. Therefore, $\mathbf{1}$ facilitates fluorometric sensing of $\mathrm{ClO}^{-}$in physiological pH range (7-9).

\subsection{Cell Imaging}

Biological experiments were performed with HeLa cells to clarify the cell permeability of $\mathbf{1}$ and applicability to the fluorescence imaging of $\mathrm{ClO}^{-}$in cells. HeLa cells were treated with a PBS/MeCN mixture $(8 / 2 v / v, \mathrm{pH} 7.4)$ containing $1(50 \mu \mathrm{M})$ for $30 \mathrm{~min}$. A PBS solution containing different concentrations of $\mathrm{ClO}^{-}(0-250 \mu \mathrm{M})$ was added to the cells and left for $30 \mathrm{~min}$. The cells were then washed with PBS, and monitored by a fluorescence microscopy $\left(\lambda_{\mathrm{ex}}=470 \mathrm{~nm} ; \lambda_{\mathrm{em}}=535 \mathrm{~nm}\right)$. As shown in Figure 7b, the cells treated with $\mathbf{1}$ alone show almost no fluorescence. However, as shown 
in Figure 7d,f,h, the cells treated with $\mathrm{ClO}^{-}$show bright green fluorescence, and the brightness clearly increases with an increase in the $\mathrm{ClO}^{-}$concentrations, although the $\mathrm{ClO}^{-}$concentrations required for bright emission are much higher than the physiologically relevant $\mathrm{ClO}^{-}$concentrations $(5-25 \mu \mathrm{M})$ [35].

1
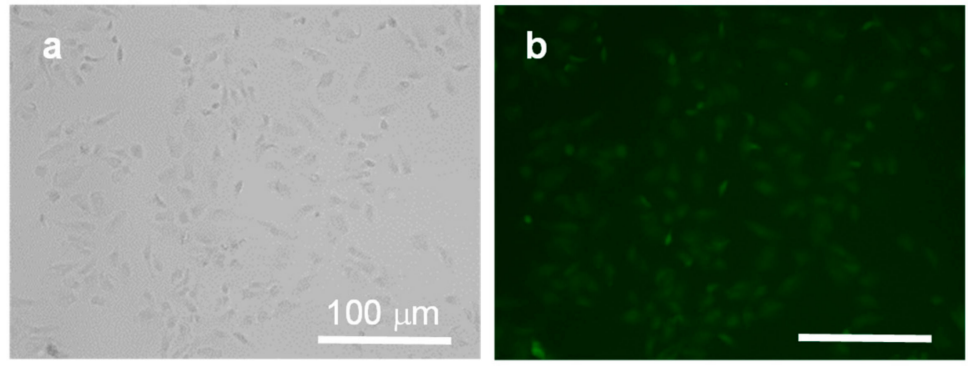

$1+\mathrm{OCl}^{-}(50 \mu \mathrm{M})$
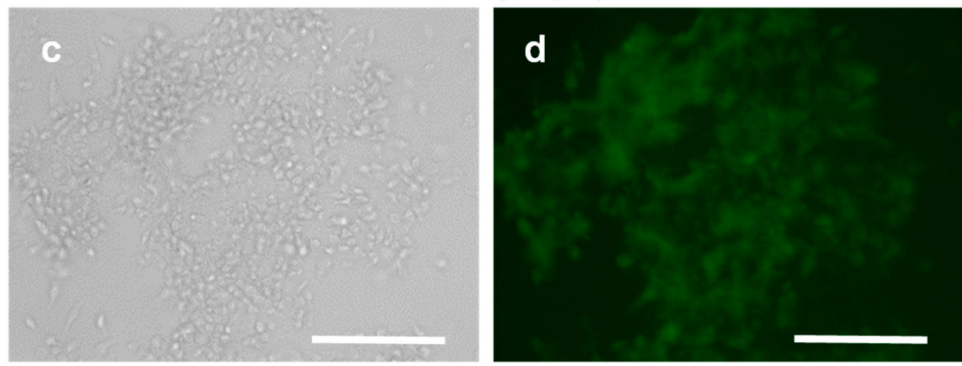

$1+\mathrm{OCl}^{-}(200 \mu \mathrm{M})$
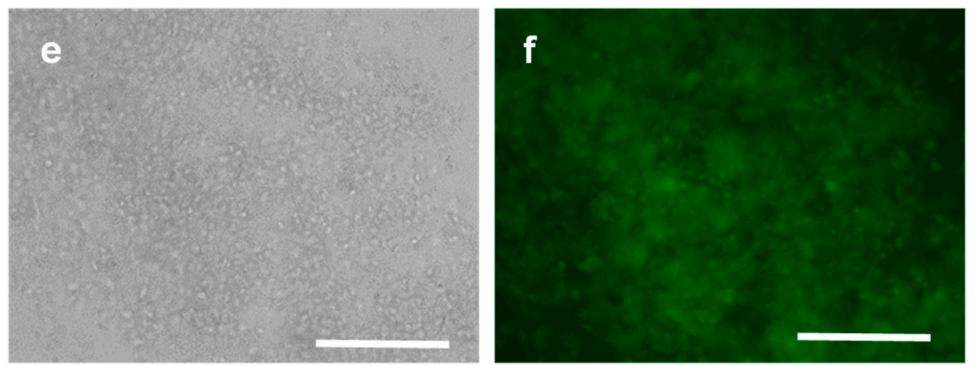

$1+\mathrm{OCl}^{-}(250 \mu \mathrm{M})$
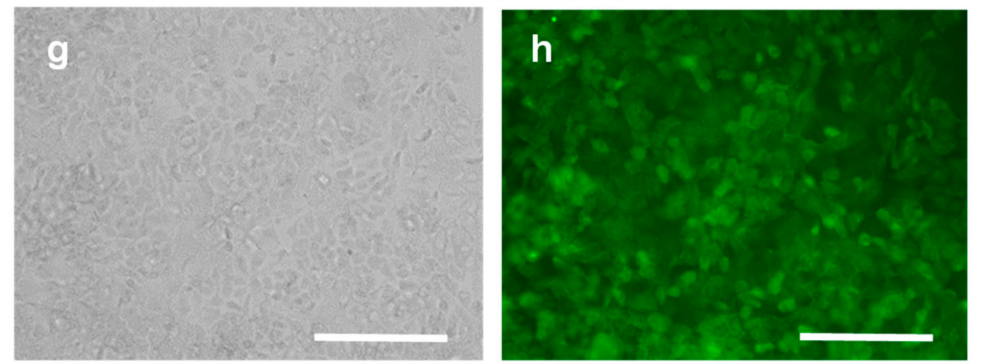

Figure 7. Fluorescence images $\left(\lambda_{\mathrm{ex}}=470 \mathrm{~nm}, \lambda_{\mathrm{em}}=535 \mathrm{~nm}\right)$ of HeLa cells treated with $50 \mu \mathrm{M}$ of 1 without or with different concentrations of $\mathrm{ClO}^{-}$. $(\mathbf{a}, \mathbf{c}, \mathbf{e}, \mathbf{g})$ Bright field images and $(\mathbf{b}, \mathbf{d}, \mathbf{f}, \mathbf{h})$ fluorescence images, respectively.

To clarify the toxicity of the cell treatment, viability of the HeLa cells before and after treatment with a PBS/MeCN (8/2/v/v) solution containing 1 was determined. A Trypan blue solution was added to the cells, and the respective live and dead cells were counted. The cell viability after the treatment was only ca. $11 \%$, although the cell viability before the treatment was ca. $96 \%$. This means that the cell treatment with the PBS/MeCN solution containing 1 leads to a loss of the functionality for almost all of the cells. In the present case, the use of $\mathrm{MeCN}$ with high cytotoxicity is necessary for permeation of the 
chemodosimeter into the cells due to its low solubility in water. Living cell imaging is therefore not facilitated by the present chemodosimeter.

\section{Conclusions}

We demonstrated that a simple naphthalimide-sulfonylhydrazine dye (1) acts as a fluorescent chemodosimeter for $\mathrm{ClO}^{-} .1$ shows almost no fluorescence, but $\mathrm{ClO}^{-}$-selective oxidative cleavage of its $\mathrm{C}=\mathrm{N}$ bond creates a strong green fluorescence owing to the suppression of intramolecular electron transfer from the photoexcited naphthalimide moiety through the $\mathrm{C}=\mathrm{N}$ bond. $\mathbf{1}$ facilitates relatively rapid ( $<10 \mathrm{~min}$ ), selective, and sensitive $\mathrm{ClO}^{-}$detection (detection limit: $1.9 \mu \mathrm{M}$ ) at $\mathrm{pH} 7-9$. The $\mathrm{C}=\mathrm{N}$ linker may therefore become a versatile design for highly efficient fluorescent chemodosimeters for $\mathrm{ClO}^{-}$. However, fluorometric imaging of $\mathrm{ClO}^{-}$in living cells was unsuccessful because use of organic solvent is necessary due to the low solubility of $\mathbf{1}$. In addition, the imaging at physiologically relevant $\mathrm{ClO}^{-}$concentrations cannot be performed due to the low reactivity of 1 with $\mathrm{ClO}^{-}$. Replacement of $p$-toluenesulfonyl hydrazine moiety to other moieties may affect the solubility to aqueous solution and the reactivity towards $\mathrm{ClO}^{-}$. These improvements are considered essential for the living cell imaging.

Supplementary Materials: Supplementary Materials can be found at http://www.mdpi.com/2227-9040/8/4/123/s1, Table S1: TD-DFT calculation results. Figure S1: ${ }^{1} \mathrm{H}$ NMR chart of 3. Figure S2: ${ }^{13} \mathrm{C}$ NMR chart of 3. Figure S3: $\mathrm{FAB}(+)-\mathrm{MS}$ chart of 3 . Figure S4: ${ }^{1} \mathrm{H}$ NMR chart of $\mathbf{1}$. Figure S5: ${ }^{13} \mathrm{C}$ NMR chart of $\mathbf{1}$. Figure S6: ${ }^{1} \mathrm{H}-{ }^{1} \mathrm{H}$ COSY chart of 1 . Figure S7: FAB(+)-MS chart of 1 . Figure S8: TLC results. Figure S9: FAB(+)-MS chart of the product by the reaction of $\mathbf{1}$ with $\mathrm{ClO}^{-}$. Figure S10: $\mathrm{FAB}(-)$-MS chart of the product by the reaction of $\mathbf{1}$ with $\mathrm{ClO}^{-}$. Cartesian Coordinates of $\mathbf{1}$. Cartesian Coordinates of 2.

Author Contributions: Writing—review and editing, Y.S.; investigation, R.N., S.T., C.Y., and T.H. All authors have read and agreed to the published version of the manuscript.

Funding: This work was partly supported by the Grant-in Aid for Challenging Exploratory Research (no. 20K21109) from the Ministry of Education, Culture, Sports, Science and Technology, Japan (MEXT).

Acknowledgments: We thank M. Nakahata and S. Sakai at the Graduate School of Engineering Science, Osaka University for their help in the cell imaging experiments.

Conflicts of Interest: The authors declare no conflict of interest.

\section{References}

1. Aoki, T.; Munemori, M. Continuous Flow Determination of Free Chlorine in Water. Anal. Chem. 1983, 55, 209-212. [CrossRef]

2. Shepherd, J.; Hilderbrand, S.A.; Waternan, P.; Heinecke, J.W.; Weissleder, R.; Libby, P. A novel fluorescent probe for the detection of myeloperoxidase activity in atherosclerosis-associated macrophages. Chem. Biol. 2007, 14, 1221-1231. [CrossRef] [PubMed]

3. Kettle, A.J.; Winterbourn, C.C. Myeloperoxidase: A key regulator of neutrophil oxidant production. Redox Rep. 1997, 3, 3-15. [CrossRef]

4. Steinbeck, M.J.; Nesti, L.J.; Sharkey, P.F.; Parvizi, J. Myeloperoxidase and chlorinated peptides in osteoarthritis: Potential biomarkers of the disease. J. Orthop. Res. 2007, 25, 1128-1135. [CrossRef]

5. Sugiyama, S.; Okada, Y.; Sukhova, G.K.; Virmani, R.; Heinecke, J.W.; Libby, P. Macrophage myeloperoxidase regulation by granulocyte macrophage colony-stimulating factor in human atherosclerosis and implications in acute coronary syndromes. Am. J. Pathol. 2001, 158, 879-891. [CrossRef]

6. Sugiyama, T.; Fujita, M.; Koide, N.; Mori, I.; Yoshida, T.; Mori, H.; Yokochi, T. 2-Aminopurine inhibits lipopolysaccharide-induced nitric oxide production by preventing IFN- $\beta$ production. Microbiol. Immunol. 2004, 48, 957-963. [CrossRef]

7. Choi, D.-K.; Pennathur, S.; Perier, C.; Tieu, K.; Teismann, P.; Wu, D.-C.; Lewis, V.J.; Vila, M.; Vonsattel, J.-P.; Heinecke, J.W.; et al. Ablation of the inflammatory enzyme myeloperoxidase mitigates features of parkinson's disease in mice. J. Neurosci. 2005, 25, 6594-6600. [CrossRef]

8. Hazen, S.L.; Hsu, F.F.; Duffin, K.; Heinecke, J.W. Molecular Chlorine Generated by the Myeloperoxidase-Hydrogen Peroxide-Chloride System of Phagocytes Converts Low Density Lipoprotein Cholesterol into a Family of Chlorinated Sterols. J. Biol. Chem. 1996, 271, 23080-23088. [CrossRef] 
9. Adam, L.C.; Gordon, G. Direct and sequential potentiometric determination of hypochlorite, chlorite, and chlorate ions when hypochlorite ion is present in large excess. Anal. Chem. 1995, 67, 535-540. [CrossRef]

10. Xu, Q.; Lee, K.A.; Lee, S.; Lee, K.M.; Lee, W.J.; Yoon, J.A. A Highly Specific Fluorescent Probe for Hypochlorous Acid and Its Application in Imaging Microbe-Induced HOCl Production. J. Am. Chem. Soc. 2013, 135, 9944-9949. [CrossRef]

11. Chen, X.; Tian, X.; Shin, I.; Yoon, J. Fluorescent and luminescent probes for detection of reactive oxygen and nitrogen species. Chem. Soc. Rev. 2011, 40, 4783-4804. [CrossRef] [PubMed]

12. Wu, D.; Chen, L.; Xu, Q.; Chen, X.; Yoon, J. Design Principles, Sensing Mechanisms, and Applications of Highly Specific Fluorescent Probes for $\mathrm{HOCl} / \mathrm{OCl}^{-}$. Acc. Chem. Res. 2019, 52, 2158-2168. [CrossRef] [PubMed]

13. Grabchev, I.; Petkov, C.; Bojinov, V. 1,8-Naphthalimides as blue emitting fluorophores for polymer materials. Macromol. Mater. Eng. 2002, 287, 904-908. [CrossRef]

14. Xiong, K.; Huo, F.; Yin, C.; Chao, J.; Zhang, Y.; Xu, M. A highly selective fluorescent bioimaging probe for hypochloritebased on 1,8-naphthalimide derivative. Sens. Actuators B 2015, 221, 1508-1514. [CrossRef]

15. Feng, H.; Zhang, Z.; Meng, Q.; Jia, H.; Wang, Y.; Zhang, R. Rapid Response Fluorescence Probe Enabled In Vivo Diagnosis and Assessing Treatment Response of Hypochlorous Acid-Mediated Rheumatoid Arthritis. Adv. Sci. 2018, 5, 1800397. [CrossRef]

16. Lee, S.C.; Kim, C. Naphthalimide-based probe for the detection of hypochlorite in a near-perfect aqueous solution. Anal. Sci. 2019, 35, 1189-1193. [CrossRef]

17. Goswami, S.; Maity, S.; Maity, A.C.; Das, A.K. Chemical Fluorometric and Naked-Eye Detectable Dual Signaling Chemodosimeter for Hypochlorite. Sens. Actuators B 2014, 204, 741-745. [CrossRef]

18. Cho, M.J.; Ryu, H.; Lee, H.J.; Chang, S. Chemical Selective Fluorescence Signaling of Hypochlorite in Tap Water by Oxidative Hydrolysis of Sulfonhydrazone. Sens Actuators B 2017, 241, 285-291. [CrossRef]

19. Qiao, L.; Nie, H.; Wu, Y.; Xin, F.; Gao, C.; Jing, J.; Zhang, X. An ultrafast responsive BODIPY-based fluorescent probe for the detection of endogenous hypochlorite in live cells. J. Mater. Chem. B 2017, 5, 525-530. [CrossRef]

20. Setsukinai, K.; Urano, Y.; Kakinuma, K.; Majima, H.J.; Nagano, T. Development of novel fluorescence probes that can reliably detect reactive oxygen species and distinguish specific species. J. Biol. Chem. 2003, 278, 3170-3175. [CrossRef]

21. Sun, Z.-N.; Liu, F.-Q.; Chen, Y.; Tam, P.K.H.; Yang, D. A Highly Specific BODIPY-Based Fluorescent Probe for the Detection of Hypochlorous Acid. Org. Lett. 2008, 10, 2171-2174. [CrossRef] [PubMed]

22. Shiraishi, Y.; Nakamura, M.; Hayashi, N.; Hirai, T. Coumarin-spyropyran dyad with a hydrogenated pyran moiety for rapid, selective, and sensitive fluorometric detection of cyanide anion. Anal. Chem. 2016, 88, 6805-6811. [CrossRef] [PubMed]

23. Shiraishi, Y.; Hashimoto, M.; Chishiro, K.; Moriyama, K.; Tanaka, S.; Hirai, T. Photocatalytic dinitrogen fixation with water on bismuth oxychloride in chloride solutions for solar-to-chemical energy conversion. J. Am. Chem. Soc. 2020, 142, 7574-7583. [CrossRef] [PubMed]

24. Bag, B.; Bharadwaj, P.K. Perturbation of the PET process in fluorophore-spacer-receptor systems through structural modification: Transition metal induced fluorescence enhancement and selectivity. J. Phys. Chem. B 2005, 109, 4377-4390. [CrossRef]

25. Proutiere, A.; Megnassan, E.; Hucteau, H. Refractive index and density variations in pure liquids: A new theoretical relation. J. Phys. Chem. 1992, 96, 3485-3489. [CrossRef]

26. Song, L.; Yang, Y.; Zhang, Q.; Tian, H.; Zhu, W. Synthesis and photochromism of naphthopyrans bearing naphthalimide chromophore: Predominant thermal reversibility in color-fading and fluorescence switch. J. Phys. Chem. B 2011, 115, 14648-14658. [CrossRef]

27. Guo, B.; Nie, H.; Yang, W.; Tian, Y.; Jing, J.; Zhang, X. A highly sensitive and rapidly responding fluorescent probe with alarge Stokes shift for imaging intracellular hypochlorite. Sens. Actuators $B$ 2016, 236, 459-465. [CrossRef]

28. Liu, Y.; Sakai, S.; Kawa, S.; Taya, M. Identification of Hydrogen Peroxide-Secreting Cells by Cytocompatible Coating with a Hydrogel Membrane. Anal. Chem. 2014, 86, 11592-11598. [CrossRef]

29. Shiraishi, Y.; Hayashi, N.; Nakahata, M.; Sakai, S.; Hirai, T. Naphthalimide-Coumarin Conjugate: Ratiometric Fluorescent Receptor for Self-Calibrating Quantification of Cyanide Anion in Cells. RSC Adv. 2017, 7, 32304-32309. [CrossRef] 
30. Sharma, N.; Reja, S.I.; Bhalla, V.; Kumar, M. A new thiacalix[4]arene-fluorescein based probe for detection of $\mathrm{CN}^{-}$and $\mathrm{Cu}^{2+}$ ions and construction of a sequential logic circuit. Dalton Trans. 2014, 43, 15929-15936. [CrossRef]

31. Mancini, M.C.; Kairdolf, B.A.; Smith, A.M.; Nie, S. Oxidative Quenching and Degradation of Polymer-Encapsulated Quantum Dots: New Insights into the Long-Term Fate and Toxicity of Nanocrystals In Vivo. J. Am. Chem. Soc. 2008, 130, 10836-10837. [CrossRef] [PubMed]

32. Greim, H.; Ahlers, J.; Bias, R.; Broecker, B.; Hollander, H.; Gelbke, H.P.; Klimisch, H.J.; Mangelsdorf, I.; Paetz, A.; Schön, N.; et al. Toxicity and Ecotoxicity of Sulfonic Acids: Structure-Activity Relationship. Chemosphere 1994, 28, 2203-2236.

33. Ortiz, G.; Liu, P.; Naing, S.H.H.; Muller, V.R.; Miller, E.W. Synthesis of Sulfonated Carbofluoresceins for Voltage Imaging. J. Am. Chem. Soc. 2019, 14, 6631-6638. [CrossRef]

34. Liu, H.; Zhang, H.; Luo, J.; Peng, J.; An, B.; Qiao, Z.; Wei, N.; Zhang, Y.; Zhu, W. Highly Efficient Cell Membrane Tracker Based on a Solvatochromic Dye with Near-Infrared Emission. ACS Omega 2020, 5, 11829-11835. [CrossRef]

35. Stratmann, R.E.; Scuseria, G.E.; Frisch, M.J. An efficient implementation of time-dependent density-functional theory for the calculation of excitation energies of large molecules. J. Chem. Phys. 1998, 109, 8218-8224. [CrossRef]

36. Nakagawara, S.; Goto, T.; Nara, M.; Ozawa, Y.; Hotta, K.; Arata, Y. Spectroscopic characterization and the $\mathrm{pH}$ dependence of bactericidal activity of the aqueous chlorine solution. Anal. Sci. 1998, 14, 691-698. [CrossRef]

37. Xu, J.; Yuan, H.; Qin, C.; Zeng, L.; Bao, G.-M. A mitochondria-targeted near-infrared probe for colorimetric and ratiometric fluorescence detection of hypochlorite in living cells. RSC Adv. 2016, 6, 107525-107532. [CrossRef]

38. Huang, Y.; Zhang, Y.; Huo, F.; Chao, J.; Yin, C. A near-infrared ratiometric fluorescent probe with large stokes based on isophorone for rapid detection of $\mathrm{ClO}^{-}$and its bioimaging in cell and mice. Sens. Actuators B 2019, 287, 453-458. [CrossRef]

39. Zha, J.; Fu, B.; Qin, C.; Zeng, L.; Hu, X. A ratiometric fluorescent probe for rapid and sensitive visualization of hypochlorite in living cells. RSC Adv. 2014, 4, 43110-43113. [CrossRef]

Publisher's Note: MDPI stays neutral with regard to jurisdictional claims in published maps and institutional affiliations.

(C) 2020 by the authors. Licensee MDPI, Basel, Switzerland. This article is an open access article distributed under the terms and conditions of the Creative Commons Attribution (CC BY) license (http://creativecommons.org/licenses/by/4.0/). 